of Sydney) for research in mathematics at Glasgow; (3) New Zealand, J. F. Young (University of Canterbury) for research in inorganic chemistry at Imperial College of Science and Technology; (4) Pakistan, E. Ahmed (University of Dacca) for research in theoretical physics (place of study to be arranged); (5) Singapore, Miss P. H. Yuen (University of Singapore) for research in zoology at the London School of Hygiene and Tropical Medicine; (6) Republic of Ireland, R. E. Burton (Trinity College, Dublin) for research in theoretical chemistry at Oxford.

\section{Courses in Applied Mechanics}

The Postgraduate Department of Applied Mechanics of the University of Sheffield will hold the following introductory courses during the academic year 1962-63: elcctronics for engineers; stress determination; fine measurement in mechanical engineering; gear design; analysis of failures of machines and structures; corrosion and fatigue; non-destructive testing; hydraulic operation and control of machines; servomechanisms and auto matic controls; gear loading, stress and life; friction wear and lubrication; analogue computing methods for engineers; noise; mochanical vibration; tech niques in control engineering. The courses are open to graduates in engineering or related subjects and to those with comparable technical training. Further information can be obtained from Prof. W. A. Tuplin, Department of Applied Mechanies, University of Sheffield, St. George's Square, Sheffield.

\section{Physics Department at Stanford University}

IN the note entitled "Nobel Prize for Physics: Prof. Robert Hofstadter" that appeared on p. 799 of the December 2, 1961, issue of Nature, it was stated that Prof. Hofstadter became head of the Physics Department at Stanford University. Prof. Hofstadter writes that this does not agree with the facts: "Prof. Leonard Schiff has been Executive Head of the Physics Department at Stanford University since July 1, 1948. Under his leadership the Physics Department has made many significant contributions to the field of physies. Throughout this long period Prof. Schiff has consistently been active in theoretical physics and he himself has made important progress in many different fields of physics". Prof. Hofstadter is, in fact, a member of Prof. Schiff's Department.

\section{University and College News:}

\section{College of Aeronautics}

THE following appointments have been announced: J. R. Busing, to be senior lecturer in the Department of Aerodynamics; K. H. Griffin, to be senior lecturer in the Department of Aircraft Design; D. Hyde, to be lecturer in the Department of Flight; D. W. McQue, to be instrumentation engineer in the Department of Electrical and Control Engineering; W. G. Bradley, to be Research Fellow in the Department of Flight.

Edinburgh

THE following appointments to lecturer have been made: Dr. M. M. Harding (chemistry); Dr. A. L. Haigh (veterinary physiology); Dr. P. Walker (zoology); Dr. M. Williamson (zoology).

Keele

THE following appointments and promotions have been made: Dr. I. M. L. Hunter to bo professor of psychology; R. Shaw to be director of extra-mural studies; Readerships, Dr. D. E. Davies (physics), Dr. R. MeWeeny (chemistry), Dr. R. ( $\mathrm{x}$. Evans (biology); Senior Lectureships, Dr. P. Halmos (psychology), Dr. C. S. Exley (geology), Dr. S. C. Nyburg (chemistry). Dr. P. H. Plesch (chemistry).

London

'THE following titles have been conferred: that of' professor of zoology on Dr. P. M. Butler in respect of his post at Royal Holloway College; that of professor of mathematics on Dr. A. Fröhlich in respect. of his post at King's College; that of professor of philosophy with special reference to sociology on Dr. F. A. Gellner in respect of his post at the London School of Economics and Political Science; that of reader in comparative education on Dr. E. J. King: in respect of his post at King's College; that of reader in physics on Dr. B. Donovan in respect of his post at Westfield College. The following appointments have been made: Dr. J. Naylor Hunt, to the chair of physiology tenable at Guy's Hospital Medical School; Dr. R. W. H. Sargent, senior lecturer at the Imperial College of Science and Technology, to the chair of chemical engineering tenable at that College; Mr. W. G. Spector, senior lecturer at University. College Hospital Medical School, to the chair of pathology tenable at St. Bartholomew's Hospital Medical College; Readerships, Dr. M. E. Fisher (physics), Dr. A. N. Davison (biochemistry), Dr. J. A. Elvidge (organic chemistry), Dr. P. J. Higgins (mathematics), Dr. D. Robinson (biochemistry), J. L. Stafford (hæmatology), Dr. M. B. Thorn (biochemistry).

University College of Swansea

THe following appointments to lectureships have been made for the session 1962-63: Mr. F. T. M. Smith (applied mathematics); Dr. C. A. Wellington (chemistry); Mr. M. J. Clarke (mechanical engineering); Mr. D. A. Watts (geography).

\section{Announcements}

Dr. Denis TAYLOR, who for the past five years has been a director and general manager of Plessey Nucleonies, Ltd., has been appointed co-ordinator of research and development for the Plessey Co., Ltd. At one time Dr. Taylor was head of the Electronies and Instrument Division of the Atomic Energy Research Establishment, Harwell.

THE Joseph P. Kennedy Jr. Foundation is offering three international awards to recognize significant achievements in the past and to assist efforts of outstanding promise in research, service and leadership concerned with mental retardation. Further information can be obtained from the Joseph P. Kennedy Jr. Foundation, 1413 K Street, N.W., Suite 306, Washington 5, D.C.

A Merting of the British Biophysical Society will be held in the Laboratory of Molecular Biology, University of Cambridge, on September 27. The programme will include a talk by Dr. M. F. Perutz. Further information can be obtained from Dr. Herman Watson, Laboratory of Molecular Biology, University Postgraduate Medical School, Hills Road, Cambridge.

THF sixth plenary meeting of the World Power Conference will be held in Melbourne during October 20-27. Further information can be obtained from the British National Committee, World Power Conference, 201--2 Grand Buildings, Trafalgar Square, London, W.C.2. 